\title{
ANALISIS SUMBER PENGETAHUAN PEMANFAATAN TUMBUHAN BERPOTENSI PANGAN PADA SUKU DAYAK TAMAMBALOH
}

\author{
Markus Iyus Supiandi ${ }^{*}$, Leliavia ${ }^{2}$ \\ 1,2 Pendidikan Biologi, STKIP Persada Khatulistiwa Sintang, Jl. Pertamina KM 4, Sengkuang, \\ Kalimantan Barat 78614, Indonesia \\ *Corresponding author, e-mail: msupiandi@gmail.com
}

\section{ABSTRACT}

The Dayak Tamambaloh tribe in West Kalimantan has local wisdom in utilizing plants that have food potential. However, knowledge of the use of plants with potential food is conveyed through verbal communication, has not been well documented, and parents who have knowledge of food plants have diminished. Therefore, knowledge of sources of knowledge of food crops is very important documented as an effort to preserve cultural heritage. This study aims to analyze the source of knowledge in utilizing food plants in the Dayak Tamambaloh tribal community. The method used in this study was a survey. Research data were obtained through interviews and literature. Data analysis using descriptive qualitative with stages: (a) data collection, (b) data reduction, (c) data presentation, (d) conclusion drawing. The results showed that the source of knowledge in utilizing plants with potential food for the Dayak Tamambaloh tribe was obtained through family, customary leaders, life experiences and trial and error.

Keywords: Analysis, Knowledge, Food Plant, Dayak Tribe, Tamambaloh

\section{PENDAHULUAN}

Kalimantan dihuni oleh beberapa kelompok etnis, salah satunya etnis Dayak (Riwut, 2007; Supiandi, dkk., 2019). Dayak merupakan sebutan bagi penduduk asli yang hidup dipulau Kalimantan (Permatasari, 2014). Suku Dayak terbagi dalam subsub suku dengan jumlah 405 sub etnis (Lontaan, 1975), salah satunya adalah sub etnis suku Dayak Tamambaloh. Suku Dayak Tamambaloh merupakan suku yang secara administratif menetap di Kabupaten Kapuas Hulu (Rike, dkk., 2018) dan berdekatan dengan Negara Malaysia. Suku Dayak Tamambaloh masih memiliki pola yang baik dalam memanfaatkan sumber daya alam, dalam hal ini memanfaatkan hasil hutan untuk memenuhi kebutuhan pangan berdasarkan kearifan lokal masyarakat setempat.

Kearifan lokal merupakan pengetahuan dasar yang diperoleh dari kehidupan yang seimbang dengan alam dan kebudayaan (Mungmachon, 2012). Kearifan lokal dapat dipahami sebagai gagasan-gagasan setempat yang bersifat bijaksana, penuh kearifan, bernilai baik, yang tertanam dan diikuti oleh anggota masyarakat (Tamelene, 2016). Kearifan lokal mewujud dalam kebiasaan-kebiasaan masyarakat yang memiliki pemahaman baik dalam bentuk material maupun nilai atau gagasan (Fadhilah, 2009). Kearifan lokal atau tradisional mengandung tiga unsur penting yaitu: (1) nilai religius dan etika sosial yang menjadi dasar dalam melakukan praktek pengelolaan sumber daya hayati, (2) norma atau aturan adat yang bertujuan untuk mengatur hubungan antar komunitas dan lingkungan alamnya, (3) pengetahuan lokal 
dan keterampilan yang diperoleh dari pengalaman empirik berpuluh-puluh tahun bahkan ratusan tahun dalam mengelola sumber daya hayati dan lingkungan. Ketiga hal tersebut menjadi satu kesatuan sistem yang menjadi landasan atau dasar tatanan kehidupan sosial, budaya, ekonomi dan politik pada komunitas masyarakat (Rahayu, 2013). Praktik kearifan lokal terkait pemanfaatan lingkungan alam sekitar sudah dilakukan sejak lama oleh masyarakat suku Dayak Tamambaloh. Pengetahuan lokal dalam hal memanfaatkan tumbuhan berpotensi pangan tersebut disampaikan secara lisan dari generasi ke generasi. Rike, dkk., (2018) menyampaikan pengetahuan tentang pemanfaatan tumbuhan lokal (tumbuhan pangan) di peroleh masyarakat melalui pengetahuan lokal baik dari pewarisan orang tua, kerabat dan sebagainya.

Pangan adalah segala sesuatu yang bersumber dari sumber hayati dan air, baik yang diolah maupun yang tidak diolah untuk konsumsi manusia sebagai makanan atau minuman (Rahayu, 2013). Sunarti, dkk., (2007) menyatakan pangan merupakan kebutuhan pokok atau dasar manusia yang terdiri dari bahan pangan hewani dan nabati (tumbuhan). Bahan pangan nabati diperoleh dari tumbuhan tingkat rendah dan tingkat tinggi. Bahan pangan yang berasal dari tumbuhan tingkat tinggi diperoleh dari hasil hutan berupa buah-buahan, dedaunan dan biji-bijian. Selanjutnya, tanaman atau tumbuhan pangan adalah kelompok tanaman sumber karbohidrat dan protein. Tanaman pangan biasanya dibatasi pada kelompok tanaman yang berumur semusim (Purwono \& Purnamawati, 2007).

Masyarakat suku Dayak Tamambaloh memanfaatkan tumbuhan sebagai bahan pangan dikarenakan: (1) ketersediaan bahan baku (tumbuhan) yang melimpah pada kawasan hutan adat, (2) sangat aman untuk dikonsumsi, (3) adanya hubungan budaya/kepercayaan setempat dalam memanfaatkan tumbuhan. Hubungan antara manusia dengan lingkungannya ditentukan oleh kebudayaan setempat sebagai pengetahuan yang diyakini serta menjadi sumber sistem nilai (Tax, 1953). Sistem pengetahuan yang dimiliki masyarakat secara tradisi merupakan salah satu bagian dari kebudayaan suku bangsa asli dan petani pedesaan (Brush, 1994).

Berdasarkan data hasil wawancara awal menunjukkan bahwa pengetahuan dalam memanfaatkan tumbuhan sebagai pangan pada masyarakat suku Dayak Tamambaloh pada saat ini mengalami suatu ancaman ke arah kepunahan karena beberapa hal: (1) disampaikan melalui komunikasi verbal, (2) belum dilakukan dokumentasi tertulis, (3) orang tua yang memiliki pengetahuan tentang tumbuhan pangan sudah semakin berkurang, (4) pengaruh budaya asing yang sudah mulai masuk pada masyarakat setempat, (5) pengaruh produk makanan dari luar negeri yang semakin mudah masuk di wilayah setempat karena secara administratif berdekatan dengan Malaysia. Oleh karena itu, analisis sumber pengetahuan tentang tumbuhan pangan pada masyarakat suku Dayak Tamambaloh menjadi semakin penting dilakukan sebagai upaya untuk melestarikan kearifan lokal masyarakat. Rohyani, dkk., (2015) mengatakan bahwa pengetahuan masyarakat tentang tumbuhan pangan dan kearifan lokal masyarakat perlu mendapat perhatian. Rohaini (2015) menyebutkan setidaknya ada lima alasan mengapa pengetahuan tradisional harus dilindungi diantaranya: (1) keadilan, (2) konservasi, (3) memelihara praktikpraktik tradisional dan budaya, (4) mencegah penyalahgunaan oleh pihak yang tidak berhak atau menghindari bio-piracy, (5) sebagai upaya promosi atas pemanfaatan dan pentingnya pengembangan pengetahuan tradisional (promotion of its use). 


\section{MET ODE}

Penelitian ini menggunakan pendekatan kualitatif. Pendekatan kualitatif digunakan karena data yang dikumpulkan adalah data deskriptif yang berupa katakata tertulis dan lisan dari masyarakat suku Dayak Tamambaloh. Metode yang digunakan adalah survei. Metode survei digunakan untuk memperoleh gambaran tentang fenomena-fenomena yang terjadi dan berkembang secara alami pada masyarakat suku Dayak Tamambaloh, dalam arti bahwa variabel penelitian tidak dimanipulasi oleh peneliti. Sumber data penelitian ini diperoleh dari masyarakat suku Dayak Tamambaloh yang memiliki pengetahuan tentang pemanfaatan tumbuhan yang berpotensi pangan antara lain: ketua adat, tokoh adat, sesepuh serta masyarakat yang sering melakukan aktivitas di hutan. Instrumen yang digunakan pada saat pengumpulan data menggunakan lembar wawancara terstruktur. Data penelitian diperoleh melalui wawancara terstruktur dengan menggunakan pertanyaan yang sudah dibuat oleh peneliti dan kajian literatur. Analisis data dilakukan secara deskriptif kualitatif dengan tahapan: (a) pengumpulan data: melakukan wawancara kepada masyarakat suku Dayak Tamambaloh yang terdiri dari ketua dan tokoh adat, sesepuh (orang yang tua pada masyarakat suku Dayak Tamambaloh) dan masyarakat yang paham tentang tumbuhan pangan (b) reduksi data: peneliti melakukan pemilihan data yang sesuai dengan tujuan penelitian yang dilakukan yakni sumber pengetahuan terkait pemanfaatan tumbuhan pangan (c) penyajian data: yaitu menyajikan data (sumber pengetahuan tentang tumbuhan pangan) dalam bentuk deskriptif (d) penarikan kesimpulan: peneliti membuat kesimpulan dari penelitian yang telah dilakukan (sumber pengetahuan terkait tumbuhan pangan) (Supiandi, dkk., 2019).

\section{HASIL DAN PEMBAHASAN}

Berdasarkan hasil wawancara pada masyarakat suku Dayak Tamambaloh menunjukkan bahwa sumber pengetahuan pemanfaatan tumbuhan berpotensi pangan diperoleh melalui: (1) keluarga, (2) ketua adat, (3) pengalaman dan cobacoba. Secara rinci penjelasannya sebagai berikut:

\section{Keluarga}

Sumber pengetahuan tentang pemanfaatan tumbuhan sebagai bahan pangan pada masyarakat suku Dayak Tamambaloh diperoleh dari keluarga secara turun temurun. Keluarga merupakan tempat yang paling tepat dan baik dalam mewariskan pengetahuan dalam memanfaatkan tumbuhan yang berpotensi pangan. Rike, dkk., (2018) menyampaikan bahwa pengetahuan tentang pemanfaatan tumbuhan lokal (pangan) di peroleh melalui pewarisan dari orang tua. Rohyani, dkk., (2015) juga menyebutkan bahwa pengetahuan masyarakat tentang tumbuhan pangan biasanya berasal dari pengetahuan yang diturunkan secara turun temurun. Keluarga menyampaikan pengetahuan tersebut secara turun temurun dengan tujuan pengetahuan tradisional tersebut tetap terjaga kelestariannya. Proses transfer pengetahuan tentang pemanfaatan tumbuhan berpotensi pangan yang diberikan oleh orang tua kepada anaknya harusnya diberikan secara bertahap dan memiliki langkahlangkah yang tepat agar anaknya (penerus) dapat menyerap dan mengimplementasikan pengetahuan tersebut dalam kehidupan sehari-hari. Proses transfer dari orang tua kepada anaknya harus dipastikan berjalan dengan baik sehingga semua 
pengetahuan yang ditansfer secara utuh dapat diterima (Cabrera-Suarez, dkk., 2001; Trevinyo-Rodriguez \& Tapies, 2006; Chirico, 2008).

\section{Ketua adat}

Sumber pengetahuan masyarakat suku Dayak Tamambaloh mengenai pemanfaatan tumbuhan sebagai pangan diperoleh dari ketua adat melalui komunikasi lisan dan disampaikan secara turun temurun. Ketua adat melakukan transfer pengetahuan tentang pemanfaatan tumbuhan pangan secara lisan dikarenakan bahwa pengetahuan lokal biasanya hanya tersimpan di dalam pikiran seseorang yang diberikan dari generasi ke generasi. Hasil penelitian ini sejalan dengan pernyataan Sithole (2007) yang menyatakan bahwa sebagian besar pengetahuan asli tersimpan di dalam pikiran seseorang dan diwariskan secara turuntemurun secara lisan. Suatu kelompok masyarakat melalui ketua adat/pemuka ataupun mitos-mitos yang beredar di masyarakat akan mengijinkan warganya memakan makanan yang boleh disantap dan dimakan (Budianto, 2004). Izin tersebut menjadi semacam pengesahan yang muncul dalam berbagai peraturan yang sifatnya normatif dan masyarakat akan patuh terhadap hal itu (Fadhilah, 2009).

\section{Pengalaman dan Coba-coba}

Sumber pengetahuan dalam memanfaatkan tumbuhan pangan pada masyarakat suku Dayak Tamambaloh diperoleh dari pengalaman dan coba-coba. Masyarakat suku Dayak Tamambaloh memiliki kedekatan dengan hutan dan aktivitas sehari-hari dilakukan diladang atau kebun yang lokasinya di hutan. Aktivitas tersebut mengakibatkan masyarakat suku Dayak Tamambaloh seringkali melihat hewanhewan yang terdapat di hutan memakan buah-buahan dan sayuran di hutan, ladang ataupun kebun yang belum pernah mereka makan. Sehingga masyarakat berpikir bahwa buah-buahan dan sayuran yang dimakan oleh hewan-hewan juga dapat dimakan oleh manusia. Berdasarkan pengalaman tersebut, maka masyarakat suku Dayak Tamambaloh mencoba untuk mengkonsumsi dan tidak terjadi apa-apa. Hal tersebut terus dilakukan hingga saat ini. Zikri, dkk., (2016) mengatakan bahwa pengetahuan tentang tumbuhan pangan diperoleh karena pengalaman hidup. Rohyani, dkk., (2015) mengatakan bahwa pengetahuan masyarakat tentang tumbuhan pangan biasanya berasal dari pengalaman hidup dan pengetahuan dari turun temurun. Fadilah (2018) menyebutkan bahwa dalam memanfaatkan tumbuhan masyarakat selalu mencoba-coba tumbuhan yang bisa dijadikan makanan.

\section{SIMPULAN}

Hasil penelitian menunjukkan bahwa masyarakat suku Dayak Tamambaloh memiliki kedekatan dengan hutan yang terlihat dari aktivitas sehari-hari dalam memanfaatkan tumbuhan pangan untuk memenuhi kebutuhan hidup. Pemanfatan alam untuk kebutuhan sehari-hari, terutama untuk pangan merupakan praktik dari pengetahuan tradisional yang dimiliki oleh masyarakat setempat. Pengetahuan tradisional tersebut diperoleh dari keluarga, ketua adat, pengalaman dan coba-coba. Pengetahuan tradisional pada masyarakat suku Dayak Tamambaloh perlu untuk didokumentasikan untuk keperluan pelestarian.

\section{UCAPAN TERIMAKASIH}

Ucapan terimakasih disampaikan kepada Perkumpulan Badan Pendidikan Karya Bangsa Sintang dan STKIP Persada Khatulistiwa Sintang yang telah membiayai penelitian ini dengan nomor kontrak penelitian 14/L-2/Penelitian.STKIP- 
PK/VIII/2018. Ucapan terimakasih juga disampaikan kepada ketua adat, tokoh adat, dan seluruh masyarakat suku Dayak Tamambaloh yang bersedia memberikan informasi terkait sumber pengetahuan tentang tumbuhan pangan kepada peneliti.

\section{REF EREN S I}

Brush, S.B. (1994). A non-market approach to proctecting biological research. In: Greaves, T. (editor). Intelectual Property Right for Indigenous People. Oklahoma City: Society for Applied Anthropology.

Budianto, I.M. (2004). Dimensi Etis terhadap Budaya Makan dan Dampaknya pada Masyarakat. Jurnal Makara Sosial Humaniora, 8 (2): 65-70.

Cabrera-Suarez K, De Sea-Perez P, \& Garcia-Almeida D. (2001). The succession process from a resource-and knowledge based view of the family firm. Family Bussiness Review, 14(1), 37-46.

Chirico, F. (2008). Knowledge Accumulation in Family Firms: Evidence from four case studies. International Small Business Journal, 26 (4): 433- 455.

Fadhilah, A. (2009). Kearifan Lokal dalam Membentuk Budaya Pangan Lokal Komunitas Molamahu Pulubala Gorontalo. (Online) tersedia di http://repository.uinjkt.ac.id/dspace/bitstream/123456789/30881/3/Amir\%2 0Fadhilah.pdf. Diakses tanggal 26 Februari 2019.

Fadilah, M. (2018). Kearifan Lokal sebagai Ketahanan Pangan. Jakarta: UIN Syarif Hidayatullah Jakarta.

Lontaan, J.U. (1975). Sejarah hukum adat dan adat istiadat Kalimantan Barat. Pontianak: Pemda Tingkat I Kalimantan Barat.

Mungmachon, M.R. (2012). Knowledge and Local Wisdom: Community Treasure. International Journal of Humanities and Social Science, 2 (13): 174-181.

Permatasari, A.I. (2014). Karangan Etnografi Kebudayaan Suku Iban di Kalimantan Barat. Indonesia: Demak.

Purwono \& Purnamawati, H. (2007). Budidaya 8 Jenis Pangan Unggul. Depok: Penebar Swadaya.

Rahayu, S. (2013). Pemanfaatan Tumbuhan Pangan dan Obat Oleh Masyarakat Kampung Sinarwangi di Sekitar Hutan Gunung Salak Kabupaten Bogor. Bogor: Departemen Konservasi Sumberdaya Hutan dan Ekowisata Fakultas Kehutanan Institut Pertanian Bogor.

Rike, N., Nita, S.T., Sungkalang, C. (2018). Ethnobotany of plant food in Dayak Tamambaloh community, West Kalimantan, Indonesia. International Journal of Academic Research and Development, 3 (3): 267-273.

Riwut, T. (2007). Kalimantan Membangun Alam dan Kebudayaan. Yogyakarta: NR Publishing.

Rohaini. (2015). Perlindungan Hukum terhadap Pengetahuan Tradisional Melalui Pengembangan Sui Generis Law (Legal Protection to Traditional Knowledge Through the Development Sui Generis Law). Fiat Justisia Jurnal Ilmu Hukum, 9 (4): 428-429.

Rohyani, I.S., Aryanti, E., \& Suripto. (2015). Potensi Nilai Gizi Tumbuhan Pangan Lokal Pulau Lombok sebagai Basis Penguatan Ketahanan Pangan Nasional. Jurnal Sains Teknologi \& Lingkungan, 1(1): 43-47.

Rohyani, I.S., Aryanti, E., \& Suripto. (2015). Potensi nilai gizi tumbuhan pangan lokal pulau lombok sebagai basis penguatan ketahanan pangan nasional (Probability of 
nutritional value of local food as a source for strengthening national food security). Pros Sem Nas Masy Biodiv Indon, 1 (7): 1698-1701.

Sithole, J. (2007). The challenges faced by African libraries and information centre in documenting and preserving indigenous knowledge. International federations of library association and institutions: IFLA Journal, 33 (2):117-123.

Sunarti, S., Rugayah \& Tutie, D. (2007). Tumbuhan Berpotensi Bahan Pangan di Daerah Cagar Alam Tengkale. Biodiversitas, 8 (2): 88-91.

Supiandi, M.I., Mahanal, S., Zubaidah, S., Julung, H., Ege, B. (2019). Ethnobotany of traditional medicinal plants used by Dayak Desa Community in Sintang, West Kalimantan, Indonesia. Biodiversitas, 20 (5): 1264-1270,

Tamalene, M.A. (2016). Perspektif Konservasi Berbasis Kearifan Lokal dan Etnobiologi Keanekaragaman Hayati Suku Togutil di Pulau Halmahera sebagai Bahan Pengembangan Buku Referensi Etnokonservasi. Malang: Universitas Negeri Malang.

Tax, S. (1953). An Appraisal of Anthropologi Today. Chicago: University of Chicago Press.

Trevinyo-Rodriguez, R.N \& Tapies, J. (2006). Effective knowledge transfer in family firms. In: P. Z. Poutziouris, K. X. Smyrnios and S. B. Kein, eds. Handbook of Research on Family bussiness. Cheltenham, UK: Edwar Elgar Publishing Limited, pp. 343-357.

Zikri, M., Hikmat, A., \& Zuhud, E.A.M. (2016). Retensi Pengetahuan Tumbuhan Pangan Suku Rejang di Kampung Rindu Hati Dalam Ketahanan Pangan (Retention of Knowledge for Food Plants Rejang Tribe at Rindu Hati Village in Food Security). Media Konservasi, 21 (3): 270-277. 